\title{
Using the Audit Risk Model in an ERP Environment: Evidence From Canada and China
}

\author{
Nabil Messabia \\ Université du Québec en Outaouais \\ Abdelhaq Elbekkali \\ Université Internationale d'Agadir \\ Michel Blanchette \\ Université du Québec en Outaouais
}

\author{
Xiaoling Xing \\ Shaoxing University
}

\begin{abstract}
This paper examines the practical use of The Audit Risk Model (ARM) in Enterprise Resources Planning (ERP) settings. International Auditing Standards (IAS) suggest that auditors of financial statements rely on the ARM to plan audit engagements. Sixty practicing auditors (30 from Canada and 30 from China) performed risk assessments on Audit Risk (AR), Inherent Risk (IR) and Control Risk (CR) in light of identical case materials. Our findings suggest that there is no significant difference between Canadian and Chinese auditors when interpreting similar data to establish their risk assessments. Nevertheless, the information regarding ERP caused the biggest discrepancy both between and within the two groups.
\end{abstract}

Keywords: audit risk, Canada, China, control risk, ERP, IAS, inherent risk, risk assessment

\section{INTRODUCTION}

Auditors often rely on a risk-based approach when it comes to assessing the sufficiency of audit evidence. Obtaining such evidence is subject to practical constraints making it impossible for auditors to ascertain absolute assurance that financial statements are free of material misstatement. Audit procedures to obtain sampling-based audit evidence can only reduce the unavoidable risk of expressing inappropriate audit opinion when the financial statements are materially misstated. That is the so-called audit risk, an intrinsic characteristic to any audit engagement. Therefore, audit can only provide reasonable assurance that the financial statements are exempt of material misstatements. In order to reduce that risk, the auditor shall comply with audit standards. Among other things, those standards require audit procedures to be applied in a timely manner so that, sufficient and appropriate evidence is obtained depending on the level of audit risk the auditor is willing to accept (Shaub, 1996). 
According to the International Auditing Standards (IAS), auditors may use a mathematical audit risk model as a tool to take into account the risk in planning and performing financial statements audit. IAS200states that: "The auditor may make use of a model that expresses the general relationship of the components of audit risk in mathematical terms to arrive at an acceptable level of detection risk. Some auditors find such a model to be useful when planning audit procedures" IAS200-A36.

The audit risk model (ARM) allows auditors to apply a systematic method which takes into account material risk factors of engagements. The most widely accepted audit risk model is the one that presumes audit risk to be a multiplicative function of inherent risk, control risk and detection risk (Messier and Austen, 2000; Libby et al., 1985).

Judgment and decision-making literature has shown cross-cultural differences in risk perception particularly between Westerners and Chinese accountants (Weber and Hsee, 2000; Weber and Morris, 2010; Nolder and Riley, 2014; Lesch et al., 2016). For instance, Weber and Hsee (2000) found that "Chinese are less risk averse in their risky financial decisions than their counterparts in the US" (p. 42). In addition to culture and nationality, context effects have been shown to be crucial determinants of risk judgments (Hermand et al., 2003). In contrast, several other studies failed to provide evidence that cross-culture differences affect risk assessments or professional judgment (Harzing and Pudelko, 2016; Hu et al., 2013; Hughes et al., 2009).

The objective of this research is to investigate the practical use of the audit risk model by auditors of financial statements of firms using complex information systems. More specifically, we examine whether, from an individual point of view, the assessments of the model's risk components are consistent from one auditor to another in an Enterprise Resource Planning (ERP) context. Cultural dimension is also considered through the involvement of auditors from Canada and from China as study participants.

Our contribution consists of addressing a literature gap in the areas of auditing and IT. Indeed, the audit risk model has captured the interest of many audit researchers, just like the link between information technology (IT) and the financial audit has. However, to the best of our knowledge, no studies investigate the impact of client ERP information on auditors risk assessment decisions, even though several studies have examined the relationship between risks in general and ERP, as discussed below in our literature review. Besides, no studies address this issue from an international perspective, which is one more contribution of this paper. The remainder of the paper is structured as follows. Section 2 discusses literature background and develops our research questions. Section 3 describes the method. Section 4 presents the results. Section 5 summarises the findings and comments the study limitations. In Section 6, we conclude and recommend avenues for future research.

\section{BACKGROUND AND RESEARCH QUESTION DEVELOPMENT}

\section{The Audit Risk Model}

The following equation presents the audit risk model which has been providing, since the $70 \mathrm{~s}$, conceptual framework for both the auditing standards and the auditing literature (Amin, 2011; Akresh, 2010; Chang et al., 2008):

$\mathrm{AR}=\mathrm{IR} \times \mathrm{CR} \times \mathrm{DR}$, or also, $\mathrm{AR}=\mathrm{RMM} \times \mathrm{DR}$ where

- AR (Audit Risk): Risk that the auditor does not make any qualification in his report on financial statements containing material misstatements;

- IR (Inherent Risk): Risk that the financial statements contain material misstatements, without taking into account the internal controls set up by the entity being audited;

- CR (Control Risk): Risk that the financial statements contain material misstatements that the internal controls set up by the entity being audited cannot prevent, detect or correct in timely manner;

- $\quad$ RMM (Risk of Material Misstatement): The product of IR and CR; 
- DR (Detection Risk): "The risk that the procedures performed by the auditor to reduce audit risk to an acceptably low level will not detect a misstatement that exists and that could be material, either individually or when aggregated with other misstatements" ISA $200 \mathrm{~s} .13 \mathrm{n}$ (ii).

It should be noted that the ultimate objective of this model is to determine the extent of the substantive or validation tests. The extent of these tests (mirroring audit hours dedicated to the engagement) is inversely proportional to the DR level. Unlike other components of the model, the DR is not set by the auditor. Rather, it is mathematically calculated using the model equation. In practice, the auditor starts by assessing the AR, IR and CR based upon the engagement's risk factors (Libby et al., 1985). Those assessments are not exempt from possible cognitive biases (Wustemann, 2004). As stated in the application guide and other explanatory Material no. IAS 200-A32: "The assessment of risks is a matter of professional judgment, rather than a matter capable of precise measurement" (IAASB, 2014, p. 91). For the purpose of evaluating the AR, any factor that is likely to reassure the auditor will result in a higher acceptable audit risk. Conversely, any worrisome factor will lead the auditor to lower the acceptable AR level. As for the IR and CR, these components will increase with the presence of perceived factors of risk and will decrease with the presence of perceived factors of assurance.

The auditor then determines the extent of the work by estimating the DR based on the resolution of the model equation, i.e., $\mathrm{DR}=\mathrm{AR} / \mathrm{RMM}$. This equation means that any decision made by the auditor regarding the AR level, as well as any evaluation regarding the IR and the CR, will mathematically and directly affect the DR. In turn, the extent of the corroborative procedures to be carried out will be affected as well (Chang et al., 2008; Colbert and Weirich, 2006; Houston et al., 1999; Libby et al., 1985).

For an auditor, assessing the elements of the audit risk model means bringing together those factors that should be considered in planning the current engagement, combining and weighting them in order to form risk judgments (Bedard and Graham, 2002).

The academic literature has conceptually criticised the mathematical equation of the audit risk model (Allen et al. 2006; Waller, 1993; Cushing and Loebbecke, 1983). One of its most criticised aspects is the multiplicative form of the equation presuming lack of interdependence among its components (Dusenbury et al. 2000; Messier and Austen, 2000; Huss et al. 2000; Haskins and Dirsmith, 1995). Despite critics, the model has been providing conceptual guidance for financial statements audit for almost half a century now (Akresh, 2010; Allen et al., 2006).

Table 1 lists examples of factors influencing risk assessment according either to literature or to auditing standards.

TABLE 1

EXAMPLE OF FACTORS INFLUENCING THE COMPONENTS OF THE AUDIT RISK MODEL

\begin{tabular}{|l|l|l|}
\hline \multicolumn{2}{|c|}{ Component/Reference } & Examples of factors potentially influencing components assessment \\
\hline \multirow{2}{*}{} & Amin (2011) & $\begin{array}{l}\text { Extent of external users relying on financial statements; Possibility of } \\
\text { client difficulties after issuing financial statements; Management } \\
\text { integrity. }\end{array}$ \\
\cline { 2 - 3 } & $\begin{array}{l}\text { Bedard and } \\
\text { Rraham (2002) } \\
\text { failure. }\end{array}$ \\
\cline { 2 - 4 } & $\begin{array}{l}\text { Houston et al. } \\
(1999)\end{array}$ & $\begin{array}{l}\text { Poor financial condition and high stock price variability; Policies audit } \\
\text { firms may have that set AR at predetermined levels. }\end{array}$ \\
\hline
\end{tabular}




\begin{tabular}{|c|c|c|}
\hline \multicolumn{2}{|c|}{ Component/Reference } & Examples of factors potentially influencing components assessment \\
\hline & IAS 200- A33 & $\begin{array}{l}\text { As a counterexample, according to this standard, the auditor's business } \\
\text { risks such as loss from litigation and adverse publicity are not factors } \\
\text { potentially influencing AR assessment. }\end{array}$ \\
\hline \multirow{4}{*}{ 竞 } & $\operatorname{Amin}(2011)$ & $\begin{array}{l}\text { Nature of client's business; Results of previous audits; Initial or repeat } \\
\text { engagement; Related parties; Non-routine transactions; Situations where } \\
\text { judgment is required; Make-up of population. }\end{array}$ \\
\hline & $\begin{array}{l}\text { Wustemann } \\
(2004)\end{array}$ & $\begin{array}{l}\text { Mobility of assets; Valuation methods that are dependent on } \\
\text { assumptions; General economic situation; Technological development. }\end{array}$ \\
\hline & $\begin{array}{l}\text { Messier and } \\
\text { Austen }(2000)\end{array}$ & $\begin{array}{l}\text { Profitability relative to the industry; Sensitivity of operating results to } \\
\text { economic factors; Going concern problems; Prior audits; Management } \\
\text { turnover, reputation and accounting skills. }\end{array}$ \\
\hline & IAS 200- A38 & $\begin{array}{l}\text { Accounts subject to complex calculations or significant estimation } \\
\text { uncertainty; Technological developments; Lack of sufficient working } \\
\text { capital to continue operations; Declining industry characterised by large } \\
\text { number of business failures. }\end{array}$ \\
\hline \multirow{3}{*}{ 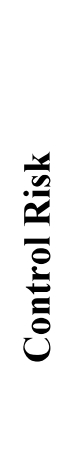 } & $\operatorname{Amin}(2011)$ & $\begin{array}{l}\text { Auditability of financial statements; Preliminary evaluation of CR; Real } \\
\text { CR assessment. }\end{array}$ \\
\hline & $\begin{array}{l}\text { Messier and } \\
\text { Austen (2000) }\end{array}$ & $\begin{array}{l}\text { Business planning, budgeting and monitoring of performance; } \\
\text { Management attitude and actions regarding financial reporting; } \\
\text { Management consultation with auditors; Management concerns about } \\
\text { external influences; Personnel policies and procedures; Audit committee } \\
\text { and internal audit function. }\end{array}$ \\
\hline & IAS 200- A39 & $\begin{array}{l}\text { Possibility of human errors or mistakes; Possibility of controls being } \\
\text { circumvented by collusion or inappropriate management override. }\end{array}$ \\
\hline
\end{tabular}

\section{Characteristics of the Audit in an ERP Environment}

Following the financial scandals at the beginning of the century (Enron, Worldcom, etc.), new regulations (for example, the Sarbanes-Oxley Act or SOX in 2002 in the United States, C-198 Act of 2002 in Canada, the Financial Security Act of 2003 in France), came into effect to reinforce the controls in general, and information system (IS) controls in particular. The risk of the IS not being adequate to support operations has become a crucial element for auditors in assessing controls (Bedard et al., 2005). This represents a paradigm shift in the auditing profession in which the audit has moved from a focus on accounting transactions and transaction control systems to the assessment of IS reliability (O'Donnell, Arnold and Sutton, 2000). The emphasis is now placed on the internal systems which control the design, the development, the implementation and the monitoring of IS, areas with which accounting professionals are less familiar. Brazel and Agoglia (2007) believe that the auditor should possess minimal expertise in this area. According to Bedard et al. (2005), auditors are aware of risk factors related to control activities caused by IT, but they do not adjust their planning decisions for the audit engagements accordingly.

Planning an audit engagement is more challenging in complex environments of accounting information systems, such as ERP, than in traditional systems (Brazel and Agoglia, 2007). This is because the implementation of an ERP system by the client is both reassuring and worrisome as far as the audit engagement is concerned. "ERP systems though sophisticated and robust do come with baggage that 
heightens control risk concerns among auditors" (Nwankpa and Datta, 2012, p. 68). Table 2 enumerates various features of ERP systems that may be perceived by auditors as source of reassuring.

TABLE 2

ERP FEATURES PERCEIVED AS SOURCE OF REASSURING

\begin{tabular}{|l|l|}
\hline \multicolumn{1}{|c|}{ Authors } & \multicolumn{1}{c|}{ ERP features lowering risk concerns } \\
\hline $\begin{array}{l}\text { Tian and } \\
\text { Xu (2015) }\end{array}$ & $\begin{array}{l}\text { ERP systems can have three effects that help lower firm risk: automation, standardization, } \\
\text { and integration; Post-implementation ERP systems can reduce firm risk; ERP systems } \\
\text { with a greater scope of functional and operational modules have strong risk reduction } \\
\text { effect. }\end{array}$ \\
\hline $\begin{array}{l}\text { Szivós and } \\
\text { Orosz }\end{array}$ & $\begin{array}{l}\text { ERP systems that incorporate a Data Consistency Check Tool can guarantee that the } \\
\text { master data is valid in all respects. }\end{array}$ \\
\hline $\begin{array}{l}\text { Morris } \\
(2011)\end{array}$ & $\begin{array}{l}\text { ERP systems facilitate auditing in two ways: they enable fast, accurate reporting and they } \\
\text { include features that facilitate implementation and enforcement of internal controls. }\end{array}$ \\
\hline $\begin{array}{l}\text { Kanellou } \\
\text { and Spathis } \\
(2011)\end{array}$ & $\begin{array}{l}\text { ERP have adequate and efficient control processes and security tools into their } \\
\text { applications. }\end{array}$ \\
\hline $\begin{array}{l}\text { Grabski et } \\
\text { al. (2011) }\end{array}$ & $\begin{array}{l}\text { ERP are perceived as appropriate mechanism to help comply with SOX requirements; } \\
\text { They offer many advantages for risk management, such as internal controls, an enhanced } \\
\text { audit trail, along with compliance and governance extensions. }\end{array}$ \\
\hline $\begin{array}{l}\text { Cao, et al. } \\
\text { (2010) }\end{array}$ & $\begin{array}{l}\text { ERP systems integrate information across the breadth and depth of the organization; They } \\
\text { achieve better timeliness in financial reporting; They streamline, automate, and effectively } \\
\text { manage internal controls. }\end{array}$ \\
\hline $\begin{array}{l}\text { Kuhn Jr. } \\
\text { and Sutton } \\
\text { (2010) }\end{array}$ & $\begin{array}{l}\text { ERP provide a critical infrastructure necessary for the effective integration of continuous } \\
\text { auditing applications. }\end{array}$ \\
\hline
\end{tabular}

Auditors do not seem to be sufficiently aware of the different risks associated with their clients using ERP. Theoretically, setting up ERP systems should lead to a general reduction in the risk level given the controls designed by the suppliers of these systems. In practice, it turns out that companies would rarely set up these controls in an appropriate way, ending up with higher risks instead (Wright and Wright, 2002).On the one hand, ERP systems should reduce IR and CR if all controls involved have been set up appropriately. On the other hand, an ERP environment can increase CR in that the same person can access several modules or functions within the organization by means of an ID, a profile and a password, which was not the case with the more traditional information systems. Moreover, monitoring is often minimal in an ERP environment. To correct this issue, some companies add extra modules to the program for internal control purposes. However, these modules are often poorly integrated into the ERP system, which further increases CR (Wright and Wright, 2002).

In contrast with the previous references, Table 3 enumerates various features of ERP systems that may be perceived by auditors as source of concern. 
TABLE 3

ERP FEATURES PERCEIVED AS SOURCE OF RISK CONCERN

\begin{tabular}{|c|c|}
\hline Authors & ERP features raising risk concerns \\
\hline $\begin{array}{l}\text { Tian and } \\
\mathrm{Xu}(2015)\end{array}$ & ERP perceived risks are embedded mainly in the adoption and implementation stages. \\
\hline $\begin{array}{l}\text { Szívós and } \\
\text { Orosz } \\
(2014)\end{array}$ & $\begin{array}{l}\text { ERP systems present data validity and consistency risks due to the use of Master Data } \\
\text { which is involved in almost each transaction. }\end{array}$ \\
\hline $\begin{array}{l}\text { Morris } \\
(2011)\end{array}$ & During implementation, some of the control features might not be activated. \\
\hline $\begin{array}{l}\text { Kanellou } \\
\text { and Spathis } \\
(2011)\end{array}$ & $\begin{array}{l}\text { ERP complexity and decentralised decision-making processes can lead to many risks; In } \\
\text { ERP environments financial auditors need the assistance of IT auditors; lack of efficient } \\
\text { cooperation with financial auditors may lead to conflicts between these two groups. }\end{array}$ \\
\hline $\begin{array}{l}\text { Grabski et } \\
\text { al. }(2011)\end{array}$ & $\begin{array}{l}\text { ERP are characterised with tightly interlinked business processes, process reengineering, } \\
\text { centralised relational database, and customization through configuration choices and } \\
\text { extensions from integrating ERP with other applications; They provide opportunities for } \\
\text { inappropriately configured access privileges to violate internal control guidelines. }\end{array}$ \\
\hline $\begin{array}{l}\text { Cao, et al. } \\
(2010)\end{array}$ & $\begin{array}{l}\text { Internal control effectiveness and audit quality can be adversely affected in ERP system } \\
\text { settings; They may contain inappropriate authorization specifications leading to increased } \\
\text { control risk; They use a large amount of master file data and can directly impact the } \\
\text { accuracy and integrity of financial reporting items. }\end{array}$ \\
\hline $\begin{array}{l}\text { Kuhn Jr. } \\
\text { and Sutton } \\
(2010)\end{array}$ & $\begin{array}{l}\text { In ERP environment, errors might not be detected in absence of sufficient audit } \\
\text { procedures; Embedded Audit Modules (EAM) may slow dramatically the ERP system; } \\
\text { EAM incorporated by external parties may transform ERP into an "un-auditable" system } \\
\text { due to a lack of independence. }\end{array}$ \\
\hline $\begin{array}{l}\text { Curtis, et } \\
\text { al. }(2009)\end{array}$ & $\begin{array}{l}\text { ERP's Automated controls may not function as expected; their controls may not be } \\
\text { activated during a system implementation, their controls may be circumvented by } \\
\text { technologically savvy employees; Their highly automated controls may provide no audit } \\
\text { trail which can complicate the audit of many processes. }\end{array}$ \\
\hline
\end{tabular}

\section{Globalization of Audit Standards in Canada and China}

The fast growth of global market in recent years has promoted the worldwide adoption of International Auditing Standards as set up by the International Auditing and Assurance Standards Board (IAASB). A growing number of national accountancy bodies and audit setters are using IAS as basis for their national auditing standards (Erchinger, 2011; AASB, 2013). The historical shift towards high-quality standards that are worthy of global acceptance happened when the IAASB completed the Clarity Project in March 2009. The project resulted in the issuance of 36 clarified IAS easy to implement worldwide (Erchinger, 2011). As of November 17, 2015, the clarified IAS were effective in 111 countries, including Canada and China (IAASB, 2016).

The Canadian Auditing and Assurance Standards Board (AASB) completed the adoption of all 36 IAS in 2009 and set their effective date to be on December 15, 2011. The list of reasons the AASB has enumerated to motivate the IAS adoption includes the rigor and transparency of the IAASB standard developing process. The format and terminology used by the IAS were also deemed appropriate in a 
Canadian context. The ability of the AASB to provide input to the IAASB in the proposed IAS was also pointed out as source of motivation (AASB, 2013).

Chinese openness to the global market has started with the adherence to the World Trade Organization in 2001. Corporate governance, financial reporting and auditing are among several areas affected by the Chinese integration into the global market economy. Convergence into international accounting and auditing standards has been running since 2006 (Zhu and Gao, 2009).

In 2005, the Chinese Institute of Certified Public Accountants (CICPA) started aligning the Chinese Auditing Standards (CAS) to the IAS (IFAC, 2006). A year later, the CICPA released the new CAS that were fully converged with IAS (IFAC, 2006; Zhu and Gao, 2009). As soon as the Clarity Project was issued by the IAASB, the CICPA carried out a new convergence project that ended on November 1, 2010 when the clarified IAS were fully incorporated into the CAS (IFAC, 2013).

\section{Cross-cultural Differences Effect on Risk Assessment}

Considering the globalization of audit standards in both Canada and China, auditors in both countries are now using basically the same set of audit standards. Does the application of a common set of auditing standards mean that Canadian and Chinese auditors would apply professional judgment to assess risk in a similar way and come to similar conclusions? Literature provides mixed insights to answer this question. On the one hand, culture differences were found to have influence on accountants' professional judgment according to several authors (Pan, and Patel, 2017; Nolder and Riley, 2014; Chand et al. 2012). On the other hand, many cross-cultural research provide evidence that acculturation and accounting education can change the cultural values of individuals so that culture impact on professional judgment might be moderated (Hu et al., 2013).

Cross-cultural studies have been largely influenced by the cultural relativism theory of Hofstede according to which cultural background might influence professional judgment (Hofstede, 2001). However, the extent to which culture affects professional judgment is perceived as overstated by many researchers such as Harzing (2016), Hu et al. (2013) and Heinz (2013). In the same vein, Patel (2004) calls for further research which explores the factors that mitigate culture effects in a way that harmonises professional judgment among accountants around the world. Globalization, technological development, accounting education have already been identified as factors that may moderate culture effects (Hu et al., 2013).

\section{Research Questions}

The audit risk model requires that the auditor be able to adequately assess the risk related to the audit engagement by assessing the three components of the model that are subject to appreciation, namely, the $\mathrm{AR}$, the IR and the CR. Recall that the auditor does not directly assess DR, the fourth component of the model. Rather, this one is calculated using the model equation. Several studies suggest that the auditor is not aware enough of the characteristics of complex IT environment to properly assess its impact on the audit process. ERP systems were presented in such prior research as typical complex IT environment (Brazel and Agoglia, 2007; Wright and Wright, 2002).

Considering that Canada and China have both adopted IAS prior to 2012, Canadian and Chinese auditors are predicted to assess similarly the elements of the audit risk model for a given engagement. It is also predicted that any specific information regarding an audit engagement should influence the assessment of the model's components in similar way whether auditors are Canadian or Chinese. We finally presume, based upon prior literature, that information regarding ERP adoption will be perceived as factor of reassuring by some auditors and as factor of risk by others. Such discrepancy is expected either between or within Canadian and Chinese groups of audit experts.

We, therefore, address the following Research Questions (RQ): RQ1- How similar are ARM components assessments made by Canadian and Chinese audit experts based upon similar background information? RQ2-How comparable is the way Canadian and Chinese audit experts use specific information to support their assessment of the model components? RQ3- Do Canadian and Chinese auditors use information referring to clients' ERP systems similarly when assessing ARM components? 


\section{METHOD}

We have conducted a survey where auditors are asked to assess the components of ARM in the financial audit of a hypothetical client described in a case. This experimental approach has been used by many audit researchers including, for instance, Brazel and Agoglia (2007), O'Donnell et al. (2000), Dusenbury, et al. (2000), Messier and Austin (2000). Sixty practicing auditors, half of them from Canada and half from China, participated in the survey. All participants belong to well-known international and national public accounting firms located in Montréal and Ottawa (Canada) and in Hangzhou and Suzhou (China).

The case provided to participants contains background information about a hypothetical client operating in the food biotech industry: the company Quedax. The case was developed and pretested by the authors. The case was sent to respondents in a survey booklet along with an introductory letter about the survey and a structured questionnaire. The introductory letter invites the respondent to play the role of Quedax's external auditor. The case includes background information about the company (such as size, control environment, competition environment) and about the audit engagement (experience with the client presented as positive). Each sentence in the case is numbered to allow identification by respondents of the specific information supporting their assessments. We intended not to include any fraud risk factor in the case background since Houston et al. (1999) provided evidence of weakness of the audit risk model when it comes to intentional errors. The provided narrative information includes a mix of risk factors (characteristics designed to raise risk concerns), reassuring factors (characteristics designed to calm risk concerns) and neutral factors for audit risks. The intent is to provide a moderate level of perceived risk for all three elements of the audit risk model.

We provided Canadian respondents with either English or French version of the booklet. Chinese respondents were provided with bilingual booklet including the same English text together with a text translated to Mandarin Chinese. The French and English versions were verified by two authors while translation from English to Mandarin went through an iterative process where a Mandarin speaking author performed a first translation of the original English text to Mandarin. A Chinese accounting student who had no access to the original English text proceeded to another translation of the Chinese text back to English. Two other authors then compared the two English versions and notified both translators of any discrepancy. Translators then adjusted their text through an iterative process until consistency was reached.

In compliance with academic requirements pertaining to research involving human participation, authors applied for and obtained a research ethics certificate delivered by the first author's university. The ethical consent form signed by the first author and by respondents clearly mentions that the questionnaire is not designed and will not be used to assess auditors' expertise.

Authors made contact with audit partners of two accounting firms in Canada and two accounting firms in China. The Canadian firms are both in the Big 4 and the Chinese firms are one Big 4 and one non-Big 4. However, the non-Big 4 Chinese firm is one of the largest CPA firms providing CPA statutory services (including audit engagements) throughout China with more than 1,000 CPAs and 3,000 employees in total.

The participating partners were requested to do the following tasks: 1) identify potential respondents from those in their firm who meet the criteria set by the researchers; 2) use e-mail to distribute the survey booklet to those identified as potential respondents; and 3) use e-mail to collect the questionnaires completed by the respondents and sending them back to the researchers. Researchers explained to their contacts that the questionnaire should be filled in by respondents who are involved, as part of their normal duties, in the planning of audit engagements.

After reading the case, participants were asked to fill in a questionnaire in which they were asked to assess each of the three components of the audit risk model and identify for each of them the specific piece of information from the Quedax case that supports their assessment. Indeed, respondents were invited to set a quote to the AR, IR and CR, using, respectively, a scale of $1 \%$ to $5 \%, 0 \%$ to $100 \%$ and $0 \%$ to $100 \%$. Respondents were also asked to indicate specifically the codes of the sentences from the background information supporting each evaluation. Providing exhaustive list of supporting information was not required. Instead, respondents were just asked to mention the most influencing sentences that underpin each component assessment.

Journal of Applied Business and Economics Vol. 22(9) 2020 
As part of the questionnaire itself, and after the section on the initial risk assessment, a paragraph adds new information on the Quedax case designed to reflect increased complexity of the company's IT environment, which reads as follows:

"During the period from 2004 to 2006, Quedax set up an ERP system, including modules for sales, payroll, financial accounting and management, as well as stock management. The sales module offers the option for clients to perform several operations online via the Quedax Web site, including the launching and following up of orders, payment, updating their own master files and requests for information. Since it was set up, the system has been considered stable and users are satisfied with it"

No attempt was made to hide this added information before the case narrative is read as our interest lies not in designing repeated measures after intervention, but in isolating the effect of this specific information.

Then respondents were invited to indicate the impact of this added information on their evaluation for the three components of the risk model. This is considered as their "adjusted" assessment based upon the ERP information. The questionnaire ended with demographic questions pertaining to respondent profile.

We pursued data gathering until we reached 60 participants and two equivalent samples of 30 respondents from each country. We intended to reach at least 30 responses per group to obtain a reasonable sample size for statistical tests.

\section{RESULTS}

\section{Variance in Assessing the Audit Risk Model Cmponents (RQ1)}

We conducted independent sample t-tests to compare the initial scores assigned by Canadian and Chinese respondents to the three model components: AR, IR and CR. The goal of the test is to assess the statistical significance of the difference, if any, between the mean scores of the two groups of respondents. Table 4 summarises the t-test results.

TABLE 4

OUTPUT SUMMARY OF INDEPENDENT SAMPLE T-TESTS

\begin{tabular}{|c|c|c|c|c|c|}
\hline & Country & $\mathbf{N}$ & $\begin{array}{c}\text { Mean } \\
(\%)\end{array}$ & Std. Dev. & $\begin{array}{c}\text { t test } \\
\text { (Sig. 2-tailed) }\end{array}$ \\
\hline \multirow{2}{*}{$\begin{array}{l}\text { 1a) Audit risk } \\
\text { (AR) }\end{array}$} & Canada & $29 *$ & 2.69 & 1.00 & \multirow{2}{*}{$\begin{array}{l}.695 \\
(\text { Levene's test sig. }=.230: \text { equal variances } \\
\text { assumed) }\end{array}$} \\
\hline & China & 30 & 2.60 & 0.72 & \\
\hline \multirow{2}{*}{$\begin{array}{l}\text { 1b) Inherent Risk } \\
\text { (IR) }\end{array}$} & Canada & $29^{*}$ & 57.93 & 21.61 & \multirow{2}{*}{$\begin{array}{l}\mathbf{7 6 5} \\
\text { (Levene's test sig.=.009: equal variances not } \\
\text { assumed) }\end{array}$} \\
\hline & China & 30 & 59.33 & 13.11 & \\
\hline \multirow{2}{*}{$\begin{array}{l}\text { 1c) Control Risk } \\
\text { (CR) }\end{array}$} & Canada & 30 & 51.67 & 21.19 & \multirow{2}{*}{$\begin{array}{l}\mathbf{1 . 0 0 0} \\
\text { (Levene's test sig.=.016: equal variances not } \\
\text { assumed) }\end{array}$} \\
\hline & China & 30 & 51.67 & 13.41 & \\
\hline
\end{tabular}

*Missing data: one respondent did not provide assessments for AR and IR.

\section{Analysis of Variance in the Use of Supporting Information (RQ2)}

As previously mentioned, respondents were asked to select from the background information the sentences they relied on to assess each of the three model components. For each of the 32 sentences of the background information, we created three dummy variables where 1 means the sentence is used to support one of the three components' assessment, and 0 means not used. The dummy variables are, then, respectively multiplied by the quote given by respondents to each of the three risk components leading to three new variables we called "Sentence\#-on-Model Component" (S\#-on-MC). Table 5 presents S\#-on-MC for the most influencing sentences respondents used to support their assessment of AR. For instance, S28on-AR stands for the calculated influence of sentence \#28, the most influencing sentence, on the assessment of AR. As shown in Table 5, the mean of S28-on-AR is $2.31 \%$ indicating that the 35 respondents $(\mathrm{N}=35)$ 
who used sentence 28 to assess AR quoted the AR at $2.31 \%$ in average. For all practical purposes, Table 5 only presents sentences that were used by $20 \%$ of all respondents, at least.

\section{TABLE 5 \\ MOST INFLUENCING SENTENCES USED TO SUPPORT ASSESSMENT OF MODEL COMPONENTS}

\begin{tabular}{|c|c|c|c|}
\hline \# & Sentence & $\mathbf{N}$ & Mean\% \\
\hline \multicolumn{4}{|c|}{ Sentences used to support assessment of AR (Sentence-on-AR) } \\
\hline 28 & $\begin{array}{l}\text { Quedax has been engaged, since last year, in intense negotiations aimed at merging } \\
\text { with a multinational company that is well-positioned for growth in an expanding } \\
\text { global market. }\end{array}$ & 35 & 2.31 \\
\hline 2 & $\begin{array}{l}\text { Your firm has audited Quedax for the last two years and past audits have always } \\
\text { resulted in unqualified audit opinions. }\end{array}$ & 28 & 2.89 \\
\hline 30 & $\begin{array}{l}\text { During the last three years, Quedax managed to keep up its profitability ratio even } \\
\text { though, at the industry level, this rate has declined as a consequence of increasingly } \\
\text { exorbitant regulations. }\end{array}$ & 28 & 2.61 \\
\hline 31 & $\begin{array}{l}\text { That was made possible by an aggressive cost cutting led by the company's top } \\
\text { management throughout the period in question. }\end{array}$ & 25 & 2.32 \\
\hline 1 & Quedax, one of the audit clients of your firm, is a publicly held company. & 21 & 2.33 \\
\hline 32 & $\begin{array}{l}\text { Cost cutting especially affected purchase and inventory control procedures, } \\
\text { technical staff training, IT investments, as well as administration expenses. }\end{array}$ & 21 & 2.48 \\
\hline 23 & $\begin{array}{l}\text { According to your experience with Quedax, accounting department employees are } \\
\text { competent but they are underpaid compared to employees from other departments. }\end{array}$ & 19 & 2.42 \\
\hline 26 & $\begin{array}{l}\text { Nevertheless, no factors appear to exist that might motivate management to override } \\
\text { existing control procedures. }\end{array}$ & 13 & 2.69 \\
\hline \multicolumn{4}{|c|}{ Sentences used to support assessment of IR (Sentence-on-IR) } \\
\hline 15 & Quedax invests in High-tech innovation projects in the biotechnology sector. & 25 & 58.40 \\
\hline 5 & It operates in the food biotechnology field. & 18 & 65.56 \\
\hline 28 & $\begin{array}{l}\text { Quedax has been engaged, since last year, in intense negotiations aimed at merging } \\
\text { with a multinational company that is well-positioned for growth in an expanding } \\
\text { global market. }\end{array}$ & 15 & 64.00 \\
\hline 30 & $\begin{array}{l}\text { During the last three years, Quedax managed to keep up its profitability ratio even } \\
\text { though, at the industry level, this rate has declined as a consequence of increasingly } \\
\text { exorbitant regulations. }\end{array}$ & 13 & 59.23 \\
\hline 13 & $\begin{array}{l}\text { It has a potential competitive advantage and an excellent outlook within a fast- } \\
\text { growing market segment. }\end{array}$ & 12 & 67.50 \\
\hline \multicolumn{4}{|c|}{ Sentences used to support assessment of CR (Sentence-on-CR) } \\
\hline 32 & $\begin{array}{l}\text { Cost cutting especially affected purchase and inventory control procedures, } \\
\text { technical staff training, IT investments, as well as administration expenses. }\end{array}$ & 33 & 55.15 \\
\hline 23 & $\begin{array}{l}\text { According to your experience with Quedax, accounting department employees are } \\
\text { competent but they are underpaid compared to employees from other departments. }\end{array}$ & 26 & 55.00 \\
\hline 26 & $\begin{array}{l}\text { Nevertheless, no factors appear to exist that might motivate management to override } \\
\text { existing control procedures. }\end{array}$ & 24 & 44.58 \\
\hline 31 & $\begin{array}{l}\text { That was made possible by an aggressive cost cutting led by the company's top } \\
\text { management throughout the period in question. }\end{array}$ & 19 & 53.68 \\
\hline 24 & $\begin{array}{l}\text { In fact, top management is under the belief that functions such as marketing and } \\
\text { production are more important and more vital to the company than the accounting } \\
\text { function. }\end{array}$ & 14 & 62.14 \\
\hline
\end{tabular}

Afterwards, we performed one-way between-groups ANOVA tests to all $96 \mathrm{~S}$-on-MC (32 sentences times 3 model components) in order to compare variances between and within the two respondent groups. 
As per ANOVA tests, we found that only the four sentences shown in Table 6 give rise to significant differences between Canadian and Chinese respondents. Therefore, the way background information was used by the two respondent groups to support the model components assessment is not significantly different except for four among the 96 combinations of sentences and model component. Note that the Levene's tests for homogeneity of variances (THV) applied to the 96 variables show that none of them reveals significant difference among the two groups in terms of variance in the scores, reflecting compliance with the homogeneity of variance assumption for effective ANOVA test.

\section{TABLE 6 \\ SENTENCES REVEALING SIGNIFICANT DIFFERENCE IN INFLUENCING THE MODEL COMPONENTS ASSESSMENT}

\begin{tabular}{|c|c|c|c|c|c|}
\hline \multirow{2}{*}{ 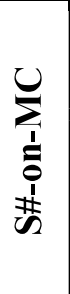 } & \multirow[b]{2}{*}{ The sentence } & \multicolumn{2}{|c|}{$\begin{array}{c}\text { Mean } \\
(\%)\end{array}$} & \multirow[b]{2}{*}{ ANOVA } & \multirow[b]{2}{*}{ Comments } \\
\hline & & $\frac{\pi}{\pi}$ & 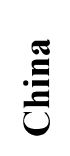 & & \\
\hline 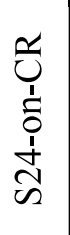 & $\begin{array}{l}\text { In fact, top management is under the belief } \\
\text { that functions such as marketing and } \\
\text { production are more important and more vital } \\
\text { to the company than the accounting function. }\end{array}$ & $\stackrel{\circ}{2}$ & $\frac{i}{n}$ & $\begin{array}{l}\mathrm{p}=.007 * * \\
(\mathrm{THV}=.147)\end{array}$ & $\begin{array}{l}\text { Significant difference } \\
\text { revealed with } \\
\text { Homogeneity of } \\
\text { Variance (HV) } \\
\text { confirmed }\end{array}$ \\
\hline 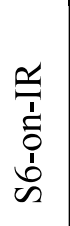 & Its stocks are listed since eight years. & $\tilde{b}$ & $\stackrel{\circ}{\circ}$ & $\begin{array}{l}\mathrm{p}=.012^{* *} \\
(\mathrm{THV}=.053)\end{array}$ & $\begin{array}{l}\text { Significant difference } \\
\text { revealed with HV } \\
\text { confirmed. }\end{array}$ \\
\hline 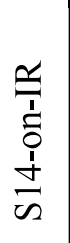 & $\begin{array}{l}\text { According to the top management, the } \\
\text { sustainability of its competitive position } \\
\text { highly depends on the expertise of its staff. }\end{array}$ & $\hat{i}$ & $\stackrel{0}{\circ}$ & $\begin{array}{l}\mathrm{p}=.037 * * \\
(\mathrm{THV}=.573)\end{array}$ & $\begin{array}{l}\text { Significant difference } \\
\text { revealed with HV } \\
\text { confirmed. }\end{array}$ \\
\hline 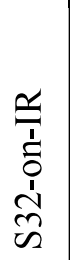 & $\begin{array}{l}\text { Cost cutting especially affected purchase and } \\
\text { inventory control procedures, technical staff } \\
\text { training, IT investments, as well as } \\
\text { administration expenses. }\end{array}$ & $\stackrel{\circ}{\circ}$ & $\begin{array}{l}0 \\
\text { in }\end{array}$ & $\begin{array}{l}\mathrm{p}=.039^{* *} \\
(\mathrm{THV}=.104)\end{array}$ & $\begin{array}{l}\text { Significant difference } \\
\text { revealed with } \mathrm{HV} \\
\text { confirmed. }\end{array}$ \\
\hline
\end{tabular}

** indicate two-tailed probabilities at $\mathrm{p} \leq 0.05$.

\section{Effect of the Information Regarding ERP (RQ3)}

When asked about the way their assessment of the three risk components would change based upon the information regarding ERP, auditors' answers show a significant disparity. As shown in Table 7, the risk component which is most affected by the information is the Control Risk. In fact, nearly two third of the respondents $([22+17] / 60)$ say they would change their assessment of the CR based upon the information regarding ERP while half $([14+16] / 60)$ would change their assessment of the AR and nearly a third 
$([11+7] / 60)$ of the IR. Nevertheless, the way assessments change differs among respondents: ERP information leads to a CR increase for some (22) and to a CR decrease for others (17). To a lower extent, similar trend could be noticed when it comes to changing AR and IR assessments based upon the ERP information.

TABLE 7

FREQUENCIES SHOWING HOW THE INFORMATION REGARDING ERP AFFECTED THE RISK COMPONENT ASSESSMENTS

\begin{tabular}{|cr|c|c|c|}
\hline & \multicolumn{2}{c}{ AR } & IR & CR \\
\hline \multirow{3}{*}{ No change } & All & 30 & 42 & 21 \\
& Canada & 16 & 19 & 10 \\
& China & 14 & 23 & 11 \\
\hline \multirow{2}{*}{ Risk increase } & All & 14 & 11 & 22 \\
& Canada & 4 & 9 & 14 \\
& China & 10 & 2 & 8 \\
\hline \multirow{2}{*}{ Risk decrease } & All & 16 & 7 & 17 \\
& Canada & 10 & 2 & 6 \\
China & 6 & 5 & 11 \\
\hline \multirow{2}{*}{ Totals } & All & 60 & 60 & 60 \\
& Canada & 30 & 30 & 30 \\
& China & 30 & 30 & 30 \\
\hline
\end{tabular}

We run Chi-square tests for independence to explore any significant difference between Canadian and Chinese respondents with respect to the effects of the ERP information on the assessment of the three risk components. In order for the Chi-square tests to be effective, at least $80 \%$ of the crosstab cells should have expected frequencies of 5 or more (Pallant, 2013). The crosstab pertaining to the IR component fails this validity test as $33 \%$ of the cells have expected count less than 5 . This makes the Chi-square test for independence non-conclusive for IR. As for AR and CR, the Chi-square tests for independence are effective and they show no dependency between country affiliation and the way the information regarding ERP use affected the assessment of these two components of the audit risk model. Indeed, as shown in Table 8, the Pearson Chi-Square related to the AR's crosstab is .157 and the one related to the CR's crosstab is equal to .207. Being both higher than .05, they show non-significant difference between the way Canadian and Chinese adjusted their AR and CR assessments based upon the ERP information.

\section{TABLE 8}

\section{CHI-SQUARE TESTS FOR INDEPENDENCE COMPARING THE ERP} INFORMATION EFFECTS

\begin{tabular}{|l|c|c|c|c|c|c|c|c|c|}
\hline \multirow{2}{*}{$\begin{array}{c}\text { Chi- } \\
\text { Square } \\
\text { Tests }\end{array}$} & \multicolumn{2}{|c|}{ Country X Revised_AR } & \multicolumn{2}{c|}{ Country X Revised_IR } & \multicolumn{2}{c|}{ Country X Revised_CR } \\
\cline { 2 - 9 } & Value & $\mathbf{d f}$ & $\begin{array}{c}\text { Asymptotic } \\
\text { Significance } \\
\text { (2-sided) }\end{array}$ & Value & df & $\begin{array}{c}\text { Asymptotic } \\
\text { Significance } \\
\text { (2-sided) }\end{array}$ & Value & df & $\begin{array}{c}\text { Asymptotic } \\
\text { Significance } \\
\text { (2-sided) }\end{array}$ \\
\hline $\begin{array}{l}\text { Pearson } \\
\text { Chi-Square }\end{array}$ & $3.705^{\mathrm{a}}$ & 2 & $\mathbf{. 1 5 7}$ & $6.121^{\mathrm{b}}$ & 2 & $\mathbf{. 0 4 7}$ & $3.155^{\mathrm{c}}$ & 2 & .207 \\
\hline $\begin{array}{l}\text { Likelihood } \\
\text { Ratio }\end{array}$ & 3.801 & 2 & .150 & 6.528 & 2 & .038 & 3.197 & 2 & .202 \\
\hline
\end{tabular}




\begin{tabular}{|l|c|c|c|c|c|c|c|c|c|}
\hline $\begin{array}{l}\text { Linear-by- } \\
\text { Linear } \\
\text { assoc. }\end{array}$ & .092 & 1 & .762 & 3.217 & 1 & .073 & 1.121 & 1 & .290 \\
\hline $\begin{array}{l}\text { N of Valid } \\
\text { Cases }\end{array}$ & 60 & & 60 & & & 60 & & & \\
\hline $\begin{array}{l}\text { Test of } \\
\text { expected } \\
\text { frequencies }\end{array}$ & $\begin{array}{l}\text { a. 0 cells (.0\%) have } \\
\text { expected count less than 5. } \\
\text { The minimum expected } \\
\text { count is 7.00. }\end{array}$ & $\begin{array}{l}\text { b. 2 cells (33.3\%) have } \\
\text { expected count less than 5. } \\
\text { The minimum expected } \\
\text { count is 3.50. }\end{array}$ & $\begin{array}{l}\text { c. 0 cells (.0\%) have } \\
\text { expected count less than 5. } \\
\text { The minimum expected } \\
\text { count is 8.50. }\end{array}$ \\
\hline
\end{tabular}

\section{DISCUSSION}

\section{Summary of the Results}

The research findings discussed above empower the argument of Bedard and Graham (2002) according to which auditors assess the ARM components by bringing together factors that should be considered in planning the engagement, combining and weighting them in order to form risk judgments. We have designed the case background in our research instrument with the intent to provide a moderate level of perceived risk for all three elements of the audit risk model. As expected, both groups of respondents (Canadian and Chinese) have initially assessed in average a moderate AR, a moderate IR and a moderate CR.

In general, there is no significant difference between Canadian and Chinese auditors when it comes to interpreting similar data in order to establish their risk assessments, especially the AR assessment. Nevertheless, four of the 32 sentences forming the case background information have shown significant interpretation difference between Canadian and Chinese. One of them affects the CR assessment and the other three affect the IR assessment. Indeed, the fact that top management underestimates the accounting function compared to other enterprise functions (sentence 24) leads Canadian auditors to establish the CR as higher than moderate while for Chinese auditors, CR remains moderate despite this factor. Significant difference is also associated with the information regarding the areas affected by the client cost cutting measures (sentence 32). While it induces both Canadian and Chinese to increase their CR assessment, only Canadian have quoted the IR as being higher than moderate based on such information. One possible explanation of the observed discrepancy with respect to interpreting the previous two pieces of information lies on the findings of Lesch et al. (2016) research about risk communications. Hence, they found that in order to communicate a similar level of risk, stronger warning labels need to be used for Chinese compared to US participants (assuming Canadian and US participants may assess risk similarly).

Also, the fact that the client's competitive position depends on the expertise of its technical staff (sentence 14) was reassuring for Canadian and neutral for Chinese with respect to IR assessment. Finally, significant difference is also observed with respect to the fact that client stock is listed since eight years (sentence 6). This information was used to support assessing IR as higher than moderate for Canadians and as lower than moderate for Chinese. These results do not seem to be aligned with the findings of Chand et al. (2012) who argued that Chinese accounting students exhibit greater conservatism compared to accounting students from Western nations such as Australia.

Combined together, the previous findings seem to support O'Donnell and Prather-Kinsey (2010) results showing variance in risk assessments depending on nationality. Their research reveals significant differences in risk assessments among auditors from different nationalities at the account level, but not in the overall risk assessments. Our study shows significant variance in the way specific pieces of information affect risk assessments even though the overall risk assessments are not subject to significant variance.

The information regarding the ERP is clearly the one that caused the biggest discrepancy both between and within the two groups of auditors. Indeed, not only auditors disagree about which of the three components' assessments is affected, but also, the same information is found to be a source of reassuring for some and source of worrisome for others. This finding supports the paradox pointed out by prior research 
(reviewed in the theoretical background above) regarding ERP risks and controls. Hence, ERP are simultaneously perceived as source of enhanced control and source of risk exposure. The primacy of either one or the other of the two perceptions may differ from auditor to auditor.

\section{Limitations of the Study}

Apart from the lack of randomness in the sampling, another limitation is the fact that we did not consider the audit methodology adopted in each of the participating audit firms. Indeed, beyond IAS, the specific audit practices used in each audit firm may have more effect on risk assessment procedures than the standards themselves. We also sacrificed relevance in favor of comparability by using a hypothetical client rather than investigating respondents' risk assessments based on their actual clients. Besides, the perception of an auditor regarding risks associated with IT complexity may depend on the auditor's own IT skills, parameter that may need to be controlled in future research. Indeed, Brazel and Agoglia (2007) have found that auditors with higher IT expertise tend to assess control risk as higher than those with lower IT expertise. Haislip et al. (2016) have also showed that auditors with more IT expertise are better able to assess the quality of internal controls. This paper works from the presumption that the ability of a financial audit expert to carry out risk-based audit planning should not be largely dependent on non-audit related skills, such as IT expertise.

Our study contains an additional sampling weakness. As mentioned above, one of the two Chinese auditing firms to which belong the respondents is not a big four, unlike the remaining participant firms. Consequences of that sampling limit may have been attenuated by the fact that the non-Big 4 Chinese firm is one of the largest CPA firms in China employing more than 1,000 CPAs.

\section{CONCLUSION}

The way professional judgment affects the assessment of the three components of the audit risk model that are subject to appreciation may lead to significant variance in risk assessment and as consequence in audit planning. In particular, we observe that both Canadian and Chinese auditors perceive ERP systems as source of higher risk for some and as source of lower risk for others. Our study contributes to the literature by confirming the paradoxical impact of ERP on audit risk assessment in practice and in an international context. Its literature contribution also lies in providing evidence of large homogeneity among Canadian and Chinese auditors both in assessing the audit risk components and in using specific pieces of information to support their assessments.

Enhancing comparability in increasingly globalised economy is one of the most pointed out arguments on behalf of IAS adoption. Nevertheless, many aspects of those standards, such as risk assessment, largely rely on professional judgment.

\section{ACKNOWLEDGEMENTS}

We much appreciate the valuable contribution of Fei Fan Chen, Samia Ferchichi and Raef Gouia who helped respectively in case translation, in data processing and in reviewing data analysis. We also thank the auditors who participated in our survey. We finally acknowledge the valuable discussion of an earlier stage of this research by Walid Ben Amor from The University of Ottawa. 


\section{REFERENCES}

AASB. (2013). Strategic Plan 2013-2016. Retrieved August 12, 2020, from http://www.frascanada.ca/auditing-and-assurance-standards-board/what-we-do/strategicplan/item73360.pdf

Akresh, A.D. (2010). A risk model to opine on internal control. Accounting Horizons, 24(1), 65-78.

Allen, R.D., Hermanson, D.R., Kozloski, T.M., \& Ramsay, R.J. (2006). Auditor risk assessment: Insights from the academic literature. Accounting Horizons, 20(2), 15777.

Amin, M.N. (2011). Audit risk model as a corporate social responsibility implementation of certified public accounting firms (evidence from Indonesia). Social Responsibility Journal, 7(3), 509-22.

Bedard, J.C., \& Graham, L.E. (2002). The Effects of Decision Aid Orientation on Risk Factor Identification and Audit Test Planning. Auditing: A Journal of Practice \& Theory, 21(2), 39-56.

Bedard, J.C., Graham, L., \& Jackson, C. (2005). Information systems risk and audit planning. International Journal of Auditing, 9(2), 147-63.

Brazel, J.F., \& Agoglia, C.P. (2007). An examination of auditor planning judgments in a complex accounting information system environment. Contemporary Accounting Research, 24(4), 105983.

Cao, J., Calderon, T., Chandra, A., \& Wang, L. (2010). Analyzing late SEC filings for differential impacts of IS and accounting issues. International Journal of Accounting Information Systems, 11(3), 189-207.

Chand, P., Cummings, L., \& Patel, C. (2012). The Effect of Accounting Education and National Culture on Accounting Judgments: A Comparative Study of Anglo-Celtic and Chinese Culture. European Accounting Review, 2l(1), 153-82.

Chang, S.I., Tsai, C.F., Shih, D.H., \& Hwang, C.L. (2008). The development of audit detection risk assessment system: Using the fuzzy theory and audit risk model. Expert Systems with Applications, 35(3), 1053-67.

Colbert, J.L., \& Weirich, T.R. (2006). The New Risk Assessment Audit Standards. Internal Auditing, 21(6), 28-39.

Curtis, M.B., Jenkins, J.G., Bedard, J.C., \& Deis, D.R. (2009). Auditors' Training and Proficiency in Information Systems: A Research Synthesis. Journal of Information Systems, 23(1), 79-96.

Cushing, B., \& Loebbecke, J. (1983, Fall). Analytical approaches to audit risk: A survey and analysis. Auditing: A Journal of Practice \& Theory, 3, 23-41.

Dusenbury, R.B., Reimers, J.L., \& Wheeler, S.W. (2000). The audit risk model: An empirical test for conditional dependencies among assessed component risks. Auditing, 19(2), 105-17.

Erchinger, H. (2011). International Standards on Auditing- Global Developments, Acting Institutions, and Status of Worldwide adoption. In V. Krivogorsky (Ed.), Law, corporate governance, and accounting: European perspectives (Routledge studies in accounting) (Vol. 9, pp. 88-105). New York (NY): Routledge.

Grabski, S.V., Leech, S.A., \& Schmidt, P.J. (2011). A Review of ERP Research: A Future Agenda for Accounting Information Systems. Journal of Information Systems, 25(1), 37-78.

Haislip, J.Z., Peters, G.F., \& Richardson, V.J. (2016). The effect of auditor IT expertise on internal controls. International Journal of Accounting Information Systems, 20, 1-15.

Harzing, A.W., \& Pudelko, M. (2016). Do We Need to Distance Ourselves from the Distance Concept? Why Home and Host Country Context Might Matter More Than (Cultural) Distance. Management International Review, 56(1), 1-34.

Haskins, M.E., \& Dirsmith, M.W. (1995). Control and Inherent Risk Assessments in Client Engagements: An Examination of Their Interdependencies. Journal of Accounting \& Public Policy, 14(1), 6383.

Heinz, P. (2013). Some theoretical and methodological suggestions for studies examining accountants' professional judgments and earnings management. Advances in Accounting, 29(2), 299-311. 
Hermand, D., Karsenty, S., Py, Y., Guillet, L., Chauvin, B., Simeone, A., \& Mullet, E. (2003). Risk target: An interactive context factor in risk perception. Risk Analysis, 23(4), 821-28.

Hofstede, G. (2001). Culture's consequences, second edition: comparing values, behaviors, institutions and organizations across nations. Sage, Thousand Oaks CA, 596 pages.

Houston, R.W., Peters, M.F., \& Pratt, J.H. (1999). The Audit Risk Model, Business Risk and AuditPlanning Decisions. The Accounting Review, 74(3), 281-98.

Hu, C., Chand, P., \& Evans, E. (2013). The effect of national culture, acculturation, and education on accounting judgments: A comparative study of Australian and Chinese culture. Journal of International Accounting Research, 12(2), 51-77.

Hughes, S.B., Sander, J.F., Higgs, S.D., \& Cullinan, C.P. 2009. The impact of cultural environment on entry-level auditors' abilities to perform analytical procedures. Journal of International Accounting, Auditing and Taxation, 18(1), 29-43.

Huss, H.F., Jacobs, F.A., Patterson, D.M., \& Park, M. (2000). An integrative model of risk management in auditing. American Business Review, 18(2), 113-22.

IAASB. (2014). Handbook of International Quality Control, Auditing, review, Other Assurance, and Related Services Pronouncements (Vol. I). New York (USA), IFAC.

IAASB. (2016). Support and Guidance. Retrieved August 12, 2020, from http://www.iaasb.org/claritycenter/support-and-guidance

IFAC. (2006). Background note on action plans. Retrieved June 16, 2020, from http://www.ifac.org/about-ifac/membership/compliance-program/compliance-responses

IFAC. (2013). Compliance Program Responses and Action Plans. Retrieved June 16, 2020, from https://www.ifac.org/about-ifac/membership/compliance-program/compliance-responses

Kanellou, A., \& Spathis, C. (2011). Auditing in enterprise system environment: A synthesis. Journal of Enterprise Information Management, 24(6), 494-519.

Kuhn, J.R., Jr., \& Sutton, S.G. (2010). Continuous Auditing in ERP System Environments: The Current State and Future Directions. Journal of Information Systems, 24(1), 91112.

Lesch, M.F., Rau, P.L.P., \& Choi, Y. (2016). Effects of culture (china vs. US) and task on perceived hazard: Evidence from product ratings, label ratings, and product to label matching. Applied Ergonomics, 52, 43-53.

Libby, R., Artman, J.T., \& Willingham, J.J. (1985). Process Susceptibility, Control Risk, and Audit Planning. The Accounting Review, 60(2), 212-30.

Messier, W.F.J., \& Austen, L.A. (2000). Inherent risk and control risk assessments: Evidence on the effect of pervasive and specific risk factors. Auditing: A Journal of Practice \& Theory, 19(2), 119-31.

Morris, J.J. (2011). The Impact of Enterprise Resource Planning (ERP) Systems on the Effectiveness of Internal Controls over Financial Reporting. Journal of Information Systems, 25(1), 129-57.

Nolder, C., \& Riley, T.J. (2014). Effects of differences in national culture on auditors' judgments and decisions: A literature review of cross-cultural auditing studies from a judgment and decision making perspective. Auditing, 33(2), 141-64.

Nwankpa, J., \& Datta, P. (2012). Perceived audit quality from ERP implementations. Information Resources Management Journal, 25(1), 61-80.

O'Donnell, E., \& Prather-Kinsey, J. (2010). Nationality and differences in auditor risk assessment: A research note with experimental evidence. Accounting, Organizations and Society, 35(5), 558-64.

O'Donnell, E., Arnold, V., \& Sutton, S.G. (2000). An analysis of the group dynamics surrounding internal control assessment in information systems audit and assurance domains. Journal of Information Systems, 14(1), 97-116.

Pallant, J. (2013). A step by step guide to data analysis using IBM SPSS: survival manual (5th Edition, p.354). McGraw Hill: Maidenhead, Berkshire, (England).

Pan, P., \& Patel, C. (2017). Construal of self and Chinese accountants' aggressive financial reporting judgments. Accounting, Auditing and Accountability Journal, 30(8), 1771-1795. 
Patel, C. (2004). Some theoretical and methodological suggestions for cross-cultural accounting studies. International Journal of Accounting, Auditing and Performance Evaluation, 1(1), 61-84.

Shaub, M.K. (1996). Trust and Suspicion: The Effects of Situational and Dispositional Factors on Auditors' Trust of Clients. Behavioral Research in Accounting, 8, 15474.

Szívós, L., \& Orosz, I. (2014). The role of data authentication and security in the audit of financial statements. Acta Polytechnica Hungarica, 11(8), 161-76.

Tian, F., \& Xu, S.X. (2015). How do enterprise resource planning systems affect firm risk? postimplementation impact. MIS Quarterly: Management Information Systems, 39(1), 3960.

Waller, W.S. (1993). Auditors' Assessments of Inherent and Control Risk in Field Setting. Accounting Review, 68(4), 783-803.

Weber, E.U., \& Hsee, C.K. (2000). Culture and individual judgment and decision making. Applied Psychology, 49(1), 32-61.

Weber, E.U., \& Morris, M.W. (2010). Culture and Judgment and Decision Making: The Constructivist Turn. Perspectives on Psychological Science, 5(4), 410-19.

Wright, S., \& Wright, A.M. (2002). Information system assurance for enterprise resource planning systems: Unique risk considerations. Journal of Information Systems, 16(1), 99-113.

Wustemann, J. (2004). Evaluation and response to risk in international accounting audit systems: Framework and German experiences. The Journal of Corporation Law, 29(2), 449 -66.

Zhu, J., \& Gao, S.S. (2009). The internationalization of China's auditing standards: Developments and challenges. Financial Sector Reform and the International Integration of China, pp. 11-27. 